\title{
Analysis of SARS-CoV-2 RNA Stability and Infectivity in Oropharyngeal Swab Samples
}

\author{
Markus Neumann \\ Robert Koch Institut \\ Daniel Bourquain \\ Robert Koch Institut

\section{Lars Schaade} \\ Robert Koch Institut \\ Andreas Nitsche \\ Robert Koch Institut
}

Marica Grossegesse ( $\nabla$ grossegessem@rki.de )

Robert Koch Institut https://orcid.org/0000-0002-9369-8203

\section{Research Article}

Keywords: SARS-CoV-2, oropharyngeal swab, infectivity, stability, sample transport

Posted Date: October 29th, 2021

DOI: https://doi.org/10.21203/rs.3.rs-892594/v2

License: (c) (i) This work is licensed under a Creative Commons Attribution 4.0 International License. Read Full License 


\section{Abstract}

The reliable detection of SARS-CoV-2 genomic RNA and infectious virus particles from patient samples requires a good sample quality. This is especially critical when the sample has to be transported to the analysing laboratory which can take several days. To determine optimal transport conditions, we simulated oropharyngeal swab samples using defined virus amounts and stored the samples at $4{ }^{\circ} \mathrm{C}$ or at room temperature for up to four days. Moreover, we analysed the influence of dry swabs in comparison to swabs stored in transport medium. Our results show that care should be taken when analysing samples for infectious SARS-CoV-2 particles since infectivity is strongly influenced by sample storage.

\section{Introduction}

The gold-standard method for the detection of SARS-CoV-2 in clinical specimens is real-time PCR. In contrast to other methods, like lateral-flow assay-based rapid antigen test, real-time PCR is highly sensitive, detecting less than 10 copies of SARS-CoV-2 RNA per reaction $[1,2]$. There is a certain correlation of the amount of viral RNA detected with real-time PCR and infectivity; e.g. from samples with low genome copy numbers the isolation of infectious virus is highly unlikely [3]. Although a potential infectivity of the sample can be deduced from a cT value, reflecting a defined number of RNA genome molecules, it remains important to test for infectious virus particles using virus isolation in cell culture in certain scenarios. For example, a basis must be provided for ending the isolation of long-term positive patients who are often immunocompromised and can have positive PCR results for up to several months after the first positive test $[4,5]$. Additionally, upon the detection of new variants of concern (VOC), infectivity testing in cell culture might be performed to elucidate how infectious virus shedding is influenced by the new variant [6]. The ability to isolate genomic viral RNA and infectious virus particles from naso- or oropharyngeal swab samples generally depends on the sampling itself, the sample transport time and temperature and, moreover, the swab type, e.g. dry or in transport medium. Additionally, patient-specific features can have an influence on the detection, e.g. the isolation of infectious virus particles likely depends on the presence of neutralizing antibodies $[7,8]$. The stability of SARS-CoV-2 has been analysed under different conditions, showing that genomic RNA and infectious virus particles are sensitive to heat and less stable on rough surfaces like wood and cloth. Additionally, the stability in aerosols has been analysed demonstrating the presence of infectious virus particles in aerosols for up to $3 \mathrm{~h}[9,10]$. However, the stability of SARS-CoV-2 genomic RNA and infectious virus particles can hardly be determined in naso-and oropharyngeal swabs, because the starting amount present in the specimen is simply unknown. Therefore, in the present study, we simulated patient samples with a defined number of infectious particles to study the stability of SARS-CoV-2 genomic RNA and infectious virus particles in oropharyngeal swab samples.

\section{Materials \& Methods}

\section{Simulation of SARS-CoV-2-positive oropharyngeal swabs and storage}


To ensure reproducibility with a defined amount of virus in the samples, SARS-CoV-2-positive oropharyngeal swabs were simulated. For this purpose, healthy laboratory staff members swabbed themselves using two common swab types: wet eSwab with amies medium (Copan, Brescia, IT, no. 490CE) and dry FLOQSwabs (Copan, Brescia, IT, no. 552c). The following steps were performed in a BSL3 laboratory. After self-testing, the swabs were transferred into 2-ml microcentrifuge tubes (Eppendorf, Hamburg, DE) containing $500 \mu$ of cell culture supernatant with a total of $5 \times 10^{3}$ PFU of SARS-2-CoV (strain BetaCoV/Germany/BavPat1/2020, kindly provided by the Institute for Microbiology of the German Armed Forces). Swabs were wiped around in the virus suspension for approximately 10 seconds and subsequently transferred into their associated storage vessels (transport medium or dry tube). Swabs in storage vessels were either stored at room temperature (RT) or in a refrigerator at $4{ }^{\circ} \mathrm{C}$. Samples for realtime PCR and virus cultivation were taken immediately, after two and four days of storage. For each time point and each swab type, samples were prepared and analysed in biological triplicate.

\section{Real-time PCR analysis}

For nucleic acid extraction the QIAamp ${ }^{\circledR}$ Viral RNA Mini Kit (Qiagen, Hilden, DE) was used. Briefly, dry swabs were vortexed in $1 \mathrm{ml}$ of PBS and $140 \mu \mathrm{l}$ were transferred into $560 \mu \mathrm{l}$ of AVL buffer. For wet swabs $140 \mu$ of storage medium were used for extraction. Viral and cellular nucleic acids were analysed using an in-house real-time PCR as described by Michel et al. [2]. In a duplex assay, both the SARS-CoV-2 orf1ab gene and the cellular MYC gene were targeted.

\section{Virus cultivation}

All samples were stored at $-80^{\circ} \mathrm{C}$ until virus cultivation. Isolation of infectious SARS-CoV-2 virions was done on VeroE6 cells (Vero C1008; ECACC 85020206) which were cultivated in DMEM medium containing $10 \%$ FCS, 1 \% L-Gln, $100 \mathrm{U} / \mathrm{ml}$ of Penicillin and Streptomycin and $50 \mathrm{mg} / \mathrm{ml}$ of Normocin ${ }^{\text {TM }}$ (Invivogen, San Diego, CA, USA). For SARS-CoV-2 infection, DMEM medium containing a reduced serum concentration of $2 \%$ FCS was used. All infection experiments were performed in a BSL-3 laboratory. Briefly, $50 \mu$ of each simulated swab sample were diluted by addition of $150 \mu$ l of infection medium. The diluted sample was used to infect one well of VeroE6 cells cultivated in 24-well cell culture plates. All samples were tested in triplicate. After $1 \mathrm{~h}$ of incubation at $37^{\circ} \mathrm{C}$ and $5 \% \mathrm{CO}_{2}$ to allow adhesion of SARSCoV-2, the diluted sample was removed and the cells were washed once in PBS, before adding $500 \mu \mathrm{l}$ of fresh medium. Subsequently, the cells were incubated at $37^{\circ} \mathrm{C}$ and $5 \% \mathrm{CO}_{2}$ for three days. At day 3 post infection (p.i.), cells were examined for signs of cytopathic effect (CPE). Furthermore, supernatant from two of the three replicate wells was harvested on day 3 and subjected to RNA extraction and real-time PCR analysis. The remaining replicate was cultivated until day 7 p.i. before it was processed equally.

\section{Virus titration $\left(\mathrm{TCID}_{50}\right)$}

A total of $2 \times 10^{4}$ VeroE6 cells per well in $100 \mu$ l of medium (DMEM $+10 \% \mathrm{FCS}+2 \mathrm{mM} \mathrm{L}$-Gln) were seeded in 96 -well plates and incubated overnight at $37^{\circ} \mathrm{C}, 5 \% \mathrm{CO}_{2}$. Samples were serially diluted in medium $\left(10^{-1}\right.$ 
to $10^{-10}$ ) and $100 \mu$ of each dilution were added in eight replicates to the cells. After incubation for five days at $37^{\circ} \mathrm{C}, 5 \% \mathrm{CO}_{2}$ the $\mathrm{CPE}$ was analysed by light microscopy and the tissue culture infectious dose 50 $\left(\mathrm{TCID}_{50}\right)$ was calculated.

\section{Results}

We simulated SARS-CoV-2 oropharyngeal swab samples and analysed the stability of viral and cellular nucleic acids after 0,2 and 4 days of storage at RT or $4^{\circ} \mathrm{C}$ using wet or dry swabs (Figure 1).

At RT, a decrease of the viral genomic RNA amount was observed over time, while it was not affected after storage at $4^{\circ} \mathrm{C}$ (Figure 2A). This was also true for cellular nucleic acids which were used as a control for effective sampling (Figure 2B). The decrease in viral genomic RNA at RT was moreover associated with a strong decrease in infectivity. No infectivity was detectable after two days of storage at RT. In contrast, infectivity was better preserved in oropharyngeal swabs stored at $4^{\circ} \mathrm{C}$ for up to four days (Table 1). At a temperature of $4^{\circ} \mathrm{C}$ no significant differences were detected between wet and dry swabs in PCR analysis for a storage time of up to four days. However, wet swabs stored at $4^{\circ} \mathrm{C}$ for up to four days showed slightly better results in the infectivity test with $67 \%$ positive culture rate compared to $22 \%$ positive culture rate for dry swabs. 
Table 1

Isolation of infectious SARS-CoV-2 particles from simulated oropharyngeal swab samples stored at room temperature (RT) and $4^{\circ} \mathrm{C}$ for up to 4 days.

\begin{tabular}{|c|c|c|c|c|c|c|c|c|c|c|c|}
\hline \multirow{2}{*}{\multicolumn{2}{|c|}{$\begin{array}{l}\text { Biological replicate } \\
\text { Technical replicate }\end{array}$}} & \multicolumn{3}{|l|}{1} & \multicolumn{3}{|c|}{2} & \multicolumn{3}{|l|}{3} & \multirow{3}{*}{$\begin{array}{l}\mathrm{TCID}_{50} / \mathrm{ml} \\
143\end{array}$} \\
\hline & & 1 & 2 & 3 & 1 & 2 & 3 & 1 & 2 & 3 & \\
\hline Dry & do & + & + & + & + & + & + & + & + & + & \\
\hline \multirow[t]{2}{*}{$4^{\circ} \mathrm{C}$} & d2 & + & + & + & + & + & + & + & - & - & 27 \\
\hline & d4 & + & - & - & + & - & - & - & - & - & N/A \\
\hline \multirow{3}{*}{$\begin{array}{l}\text { Wet } \\
4^{\circ} \mathrm{C}\end{array}$} & do & + & + & + & + & + & + & + & + & + & 89 \\
\hline & d2 & + & + & + & + & + & + & + & + & + & 61 \\
\hline & d4 & + & + & + & + & + & - & + & - & - & 13 \\
\hline \multirow{3}{*}{$\begin{array}{l}\text { Dry } \\
\text { RT }\end{array}$} & do & + & + & + & + & + & + & + & + & + & N/A \\
\hline & d2 & - & - & - & - & - & - & - & - & - & N/A \\
\hline & d4 & - & - & - & - & - & - & - & - & - & N/A \\
\hline \multirow{3}{*}{$\begin{array}{l}\text { Wet } \\
\text { RT }\end{array}$} & do & + & + & + & + & + & + & + & + & + & N/A \\
\hline & $\mathrm{d} 2$ & + & - & - & - & - & - & - & - & - & N/A \\
\hline & d4 & - & - & - & - & - & - & - & - & - & N/A \\
\hline \multicolumn{12}{|c|}{$\begin{array}{l}\text { The successful isolation of infectious virus particles is displayed by " }+ \text { ", no isolation of infectious } \\
\text { virus particles is displayed by a "-". For samples stored at } 4{ }^{\circ} \mathrm{C} \text {, the number of infectious particles wa } \\
\text { calculated }\left(\mathrm{TCID}_{50} / \mathrm{ml}\right) \text { and shown as mean of three replicates. }\end{array}$} \\
\hline
\end{tabular}

\section{Discussion}

For the detection of SARS-CoV-2 genomic RNA and the isolation of infectious virus particles, naso- or oropharyngeal swabs have to be transported from the patient to the laboratory. During transport, the majority of samples is stored at RT or, in rare cases, at $4^{\circ} \mathrm{C}$. Hence, we analysed the stability of viral genomic RNA and virus particles at these two temperatures. We used a storage time of up to four days to simulate a sample shipment taking several days. In agreement with the literature, viral nucleic acids and infectivity were better preserved at a storage temperature of $4^{\circ} \mathrm{C}$ compared to RT [9]. Moreover, at $4^{\circ} \mathrm{C}$ the amount of nucleic acids in wet and dry swabs was comparable. Surprisingly, the detection of infectious virus particles in the samples was already dramatically reduced after storage at RT for two days. From these results we recommend SARS-CoV-2 oropharyngeal swab samples designated for virus isolation in cell culture to be cooled at $4^{\circ} \mathrm{C}$ during sample transport to ensure preservation of infectious virus particles. A possibly reason for the reduction of infectivity in the samples is the presence of proteases from saliva rendering viruses non-infectious by degradation of virion proteins. Saliva is a digestive fluid 
and contains a mixture of diverse proteases, and even low amounts in oropharyngeal swab samples can potentially reduce the number of infectious virus particles [11]. Additionally, RNases present in saliva and hence in oropharyngeal swabs - can degrade SARS-CoV-2 RNA [12]. Using dry swabs, the virus particles could also be prone to dry-out, potentially explaining the slightly better preservation of infectious virus particles in wet compared to dry swabs.

The present study analyses the stability of SARS-CoV-2 genomic RNA and infectious virus particles, imitating a sample from an infected patient as closely as possible. Using oropharyngeal swabs from healthy volunteers more closely reflects the natural conditions during sample transport than plain transport medium or plain dry swabs without the saliva components present in patient samples. We conclude that samples designated for virus cultivation should be transported in medium, e.g. amies medium, cooled during transport to $4^{\circ} \mathrm{C}$ and analysed within two days to ensure a correct diagnosis.

\section{Abbreviations}

CPE: cytopathic effect

p.i.: post infection

RT: room temperature

Tissue culture infectious dose: $\mathrm{TCID}_{50}$

VOC: variant of concern

\section{Declarations}

\section{Ethics approval and consent to participate}

Not applicable

\section{Consent for publication}

Not applicable

\section{Availability of data and materials}

Not applicable

\section{Competing interests}

The authors declare that they have no conflict of interest

\section{Funding}


Not applicable

\section{Authors' contributions}

MN conceptualized the study and analysed the data. MN and MG prepared the figures and wrote the original manuscript. DB was responsible for the infectivity experiments in the BLS-3 lab. AN and LS supervised the study. All authors read and approved the final manuscript.

\section{Acknowledgements}

The authors like to thank Melanie Hoffmeister, Bianca Hube, Silvia Muschter and Stefanie Schürer for supporting the laboratory work and Ursula Erikli for copy-editing.

\section{References}

1. Corman VM, Landt O, Kaiser M, Molenkamp R, Meijer A, Chu DK et al (2020) Detection of 2019 novel coronavirus (2019-nCoV) by real-time RT-PCR. Euro Surveill 25(3):2000045. https://doi.org/10.2807/1560-7917.ES.2020.25.3.2000045

2. Michel J, Neumann M, Krause E, Rinner T, Muzeniek T, Grossegesse M et al (2021) Resource-efficient internally controlled in-house real-time PCR detection of SARS-CoV-2. Virol J 18(1):110. https://doi.org/10.1186/s12985-021-01559-3

3. Wölfel R, Corman VM, Guggemos W, Seilmaier M, Zange S, Müller MA et al (2020) Virological assessment of hospitalized patients with COVID-2019. Nature 581(7809):465-469. https://doi.org/10.1038/s41586-020-2196-x

4. Avanzato VA, Matson MJ, Seifert SN, Pryce R, Williamson BN, Anzick SL et al (2020) Case Study: Prolonged Infectious SARS-CoV-2 Shedding from an Asymptomatic Immunocompromised Individual with Cancer. Cell 183(7):1901-1912 e9. https://doi.org/10.1016/j.cell.2020.10.049

5. Li W, Huang B, Shen Q, Jiang S, Jin K, Ning L et al (2021) Persistent SARS-CoV-2-positive over 4 months in a COVID-19 patient with CHB. Open Med (Wars) 16(1):749-753. https://doi.org/10.1515/med-2021-0283

6. Davies NG, Abbott S, Barnard RC, Jarvis Cl, Kucharski AJ, Munday JD et al (2021) Estimated transmissibility and impact of SARS-CoV-2 lineage B.1.1.7 in England. Science 372(6538):eabg3055. https://doi.org/10.1126/science.abg3055

7. Sterlin D, Mathian A, Miyara M, Mohr A, Anna F, Claër L et al (2021) IgA dominates the early neutralizing antibody response to SARS-CoV-2. Sci Transl Med 13(577):eabd2223. https://doi.org/10.1126/scitranslmed.abd2223

8. Wang Z, Lorenzi JCC, Muecksch F, Finkin S, Viant C, Gaebler C et al (2021) Enhanced SARS-CoV-2 neutralization by dimeric IgA. Sci Transl Med 13(577):eabf1555. https://doi.org/10.1126/scitranslmed.abf1555 
9. Chin AWH, Chu JTS, Perera MRA, Hui KPY, Yen HL, Chan MCW et al (2020) Stability of SARS-CoV-2 in different environmental conditions. Lancet Microbe 1(1):e10. https://doi.org/10.1016/S26665247(20)30003-3

10. van Doremalen N, Bushmaker T, Morris DH, Holbrook MG, Gamble A, Williamson BN et al (2020) Aerosol and Surface Stability of SARS-CoV-2 as Compared with SARS-CoV-1. N Engl J Med 382(16):1564-1567. https://doi.org/10.1056/NEJMc2004973

11. Thomadaki K, Helmerhorst EJ, Tian N, Sun X, Siqueira WL, Walt DR et al (2011) Whole-saliva proteolysis and its impact on salivary diagnostics. J Dent Res 90(11):1325-1330. https://doi.org/10.1177/0022034511420721

12. Nishibata $Y$, Koshimoto S, Ogaki K, Ishikawa E, Wada K, Yoshinari M et al (2021) RNase in the saliva can affect the detection of severe acute respiratory syndrome coronavirus 2 by real-time one-step polymerase chain reaction using saliva samples. Pathol Res Pract 220:153381. https://doi.org/10.1016/j.prp.2021.153381

\section{Figures}

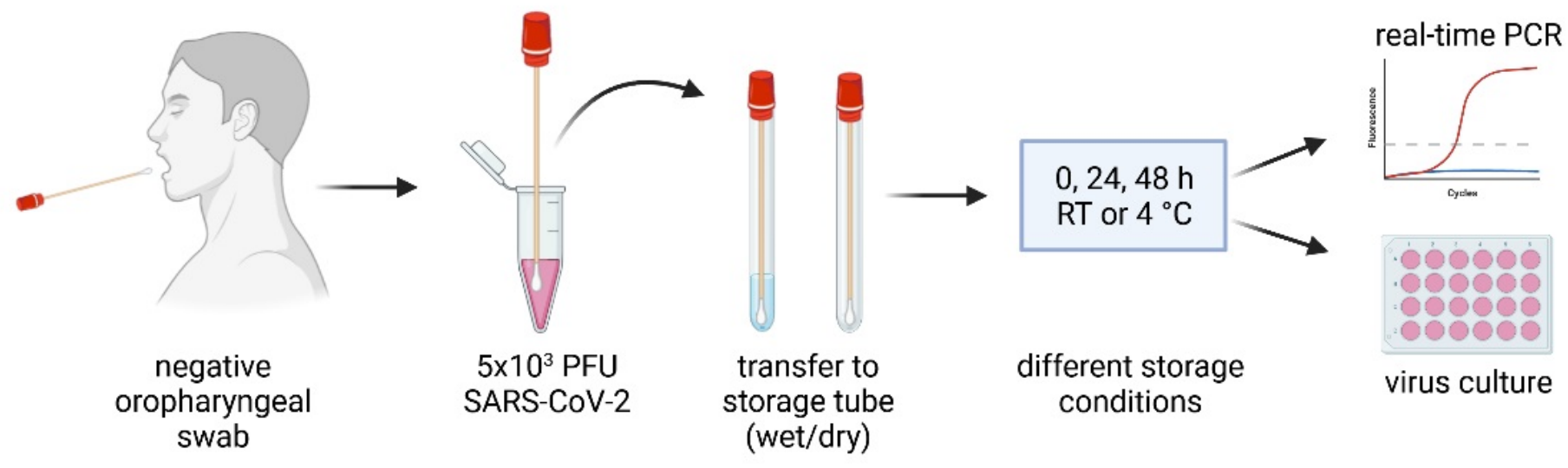

Figure 1

Experimental setup to analyse the stability of SARS-CoV-2 genomic RNA and infectivity in oropharyngeal swab samples. 

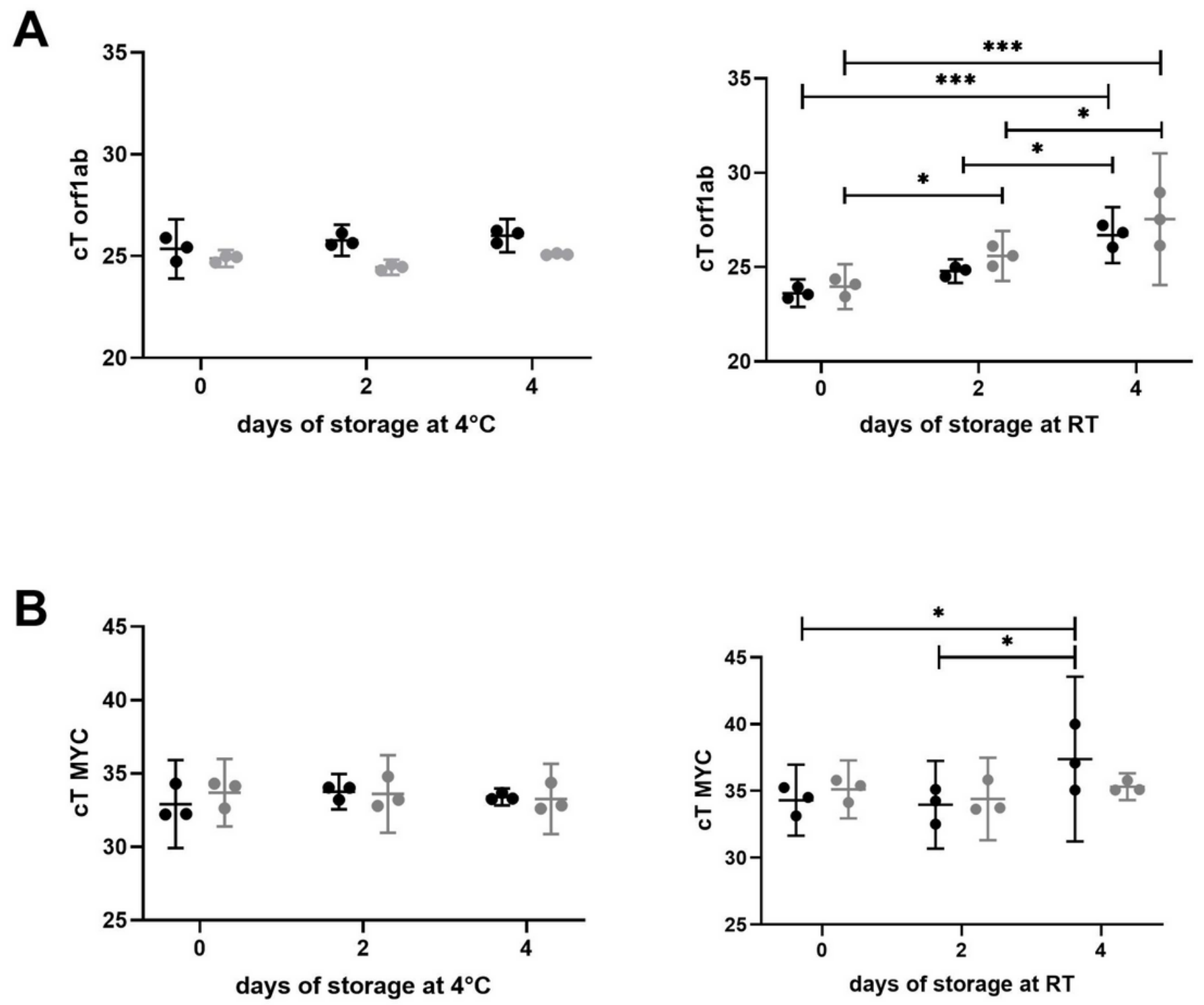

Figure 2

Stability of SARS-CoV-2 genomic RNA and cellular nucleic acids in oropharyngeal swabs. SARS-CoV-2 oropharyngeal swab samples were simulated using dry (black) or wet (grey) swabs and stored for 0,2 and 4 days at two different temperatures. (A) The viral genomic RNA (orf1ab gene) and (B) a cellular control gene (MYC) were analysed by real-time PCR. Statistics: 2-way ANOVA and Tukey's multiple comparisons test $\left({ }^{*} p \leq 0.05,{ }^{* *} p \leq 0.001\right)$. 